$\mathbf{Y}$

\section{YANSHAN UNIVERSITY}

Qinhuangdao, Hebei, China

Contact: Yanshan University

Yanshan University is a university in Qinhuangdao, Hebei, China under the provincial government. It has a student population of 39,000 and a staff population of 3,200 . It is a national key school and runs state key labs on its campus.

\section{Chinese Government Scholarship Program}

Purpose: Chinese Government Scholarship Program is established by the Ministry of Education of P.R. China in accordance with educational exchange agreements or understandings reached between the Chinese government and the governments of other countries, organizations, education institutions and relevant international organizations to provide both full scholarships and partial scholarships to international students and scholars.

Eligibility: For eligibility, please visit website http://english.ysu.edu. cn/info/2345/1095.htm

Level of Study: Doctorate, Postgraduate

Type: Scholarship

Value: Master's degree students and general scholars: CNY 1,700 Yuan; doctoral degree students and senior scholars: CNY 2,000 Yuan. Exempt from registration fee, tuition fee, fee for laboratory experiment, fee for internship, fee for basic learning materials; and accommodation fee for dormitory on campus

Length of Study: 1 to 2 years for both post graduate and doctorate degrees

\section{Country of Study: China}

Application Procedure: Please visit website http://english.ysu.edu. $\mathrm{cn} /$ info/2345/1095.htm for applications procedure.

Contributor: Yanshan University

Additional Information: The CSC Online Application System for Study in China is available on http://laihua.csc.edu.cn. The Agency No. is 10216

\section{CSC Scholarships 2018}

Purpose: The scholarship is awarded only to Ph.D. candidates. Eligibility: For eligibility refer website https://www.cscscholarships. net/yanshan-university-csc-scholarships-ranking-agency-numberand-faculty.html.

Level of Study: Doctorate

Value: Registration fee, tuition fee, and accommodation fee for dormitory on campus, monthly allowance: CNY1400 for 12 months/ year, one-off settlement subsidy: CNY 2000

Length of Study: 3 to 4 years

Country of Study: China

Application Procedure: For application procedure, please refer website https://www.cscscholarships.net/yanshan-university-cscscholarships-ranking-agency-number-and-faculty.html.

Closing Date: May of every year

\section{Yanshan University Doctoral Scholarships}

Subjects: Any of the courses offered by the university.

Purpose: The aim of the scholarships is to provide financial help to the students who are coming to study in China.

Eligibility: Non-Chinese citizens are eligible to apply for this

scholarship programme.

Level of Study: Doctorate

Type: Scholarships

Value: Registration fee, tuition fee, and accommodation fee for dormitory on campus. Monthly allowance of CNY 1400 for 12 months, one-off settlement subsidy CNY 2000

Application Procedure: Please visit website http://www.cscscholarships.org/yanshan-university-doctoral-scholarships.html for application procedures.

Closing Date: May 20th every year

Contributor: Yanshan University

Additional Information: Please visit website http://english.ysu.edu. cn/info/2345/1092.htm for more details.

\section{Yanshan University Scholarship Program for} International Students

Subjects: Scholarships are awarded to study the subjects offered by the university.

Purpose: Scholarships are available for pursuing master degree programme.

Eligibility: Non-Chinese citizens are eligible to apply. For more details, visit website http://scholarship-positions.com/yanshan-university-scholarship-program-international-students-china/2018/03/31/. Level of Study: Postgraduate

Value: First class scholarship covers the following: registration fee, tuition fee, and accommodation fee for dormitory on campus. The second class scholarship covers the following: registration fee and tuition fee

Country of Study: China

No. of awards offered: Not known

Application Procedure: The mode of applying is online. Email application to study@ysu.edu.cn.

Closing Date: May 20th

\section{YIVO INSTITUTE FOR JEWISH RESEARCH}

15 West 16th Street, New York, NY, 10011-6301, United States of America Tel: (1) 2122466080

Email: pglasser@yivo.cjh.org Website: www.yivoinstitute.org

Contact: Dr Paul Glasser, Dean, Senior Research Associate

YIVO Institute for Jewish Research was founded in 1925, in Vilna, Poland as the Yiddish Scientific Institute, the YIVO Institute for Jewish Research is dedicated to the history and culture of Ashkenazi Jewry and to its influence in the Americas.

\section{Abraham and Rachela Melezin Fellowship}

Subjects: Jewish educational networks in Lithuania.

Purpose: To support doctoral and postdoctoral research on Jewish educational networks in Lithuania, with emphasis on pre-war Vilna and the Vilna region.

Level of Study: Doctorate, Postdoctorate

Type: Fellowship

Value: US $\$ 1,500$

Length of Study: 1-3 months

Frequency: Annual

Study Establishment: YIVO Library and Archives

Country of Study: United States of America

No. of awards offered: 1

Application Procedure: Applicants must send a covering letter, curriculum vitae, research proposal and 2 letters of support through regular mail, fax or email.

Closing Date: December 31st

Additional Information: A written summary of one's research is required; a public lecture is optional.

For further information contact:

Email: pglasser@yivo.cjh.org

Contact: Dr Paul Glasser

\section{Abram and Fannie Gottlieb Immerman and Abraham Nathan and Bertha Daskal Weinstein Memorial \\ Fellowship}

Subjects: Jews of Courland and Latvia.

Purpose: To support travel for $\mathrm{PhD}$ dissertation research in archives and libraries of the Baltic states with preference given to research on the Jews of Courland and Latvia.

Eligibility: For those engaged in $\mathrm{PhD}$ dissertation research in archives and libraries of the Baltic states with preference given to research on the Jews of Courland and Latvia.

Level of Study: Doctorate

Type: Fellowship

Value: US $\$ 2,000$

Frequency: Every 2 years 
Application Procedure: Applicants must send a cover letter, curriculum vitae, research proposal and 2 letters of support through regular mail, fax or email. A written summary of one's research is required.

Closing Date: December 31st

For further information contact:

Email: pglasser@yivo.cjh.org

Contact: Dr Paul Glasser

\section{Aleksander and Alicja Hertz Memorial Fellowship}

Subjects: Polish-Jewish history.

Purpose: To encourage research on Jewish-Polish relations and

Jewish contributions to Polish literature and culture in the modern period.

Level of Study: Doctorate, Postdoctorate

Type: Fellowship

Value: US $\$ 1,500$

Length of Study: 1-3 months

Frequency: Annual

Country of Study: United States of America

No. of awards offered: 1

Application Procedure: Applicants must send their curriculum vitae, research proposal and 2 letters of support through regular mail, fax or email. A written summary of one's research is required.

Closing Date: December 31st

For further information contact:

Email: pglasser@yivo.cjh.org

Contact: Dr Paul Glasser, Chair Fellowship Committee

\section{Dina Abramowicz Emerging Scholar Fellowship}

Subjects: Eastern European Jewish studies.

Purpose: To support a significant scholarly publication that may encompass the revision of a doctoral dissertation.

Eligibility: Applicants are required to give a public lecture.

Level of Study: Postdoctorate

Type: Fellowship

Value: US $\$ 3,000$

Length of Study: 1-3 months

Frequency: Annual

Application Procedure: Applicants must send their curriculum vitae, a research proposal and 2 letters of support through regular mail, fax or email.

Closing Date: December 31st

Additional Information: Please check website for more details.

For further information contact:

Email: pglasser@yivo.cjh.org

Contact: Dr Paul Glasser, Chair, Fellowship Committee

\section{Dora and Mayer Tendler Fellowship}

Subjects: Jewish studies.

Purpose: To support graduate research in Jewish studies with preference given to research in YIVO collections.

Eligibility: Graduate applicants must carry out original research in the field of Jewish studies and give a written summary of the research carried out.

Level of Study: Doctorate, Graduate

Type: Fellowship

Value: US $\$ 3,000$

Frequency: Annual

Study Establishment: YIVO collections

Country of Study: United States of America

Application Procedure: Applicants must send a cover letter curriculum vitae, research proposal and 2 letters of support through regular mail, fax or email.

Closing Date: December 31st

Additional Information: A public lecture at the end of the tenure of the Fellowship is optional.
For further information contact:

Email: pglasser@yivo.cjh.org

Contact: Dr Paul Glasser, Chairman - Fellowship Committee

\section{Joseph Kremen Memorial Fellowship}

Subjects: Eastern European Jewish music, art and theater.

Purpose: To financially assist researchers at the YIVO Archives and Library.

Eligibility: A written summary of one's research is required.

Level of Study: Postgraduate, Research

Type: Fellowship

Value: US $\$ 2,000$

Frequency: Annual

Application Procedure: Applicants must send their curriculum vitae, research proposal and 2 letters of support by regular mail, fax or email.

Closing Date: December 31st

For further information contact:

Email: pglasser@yivo.cjh.org

Contact: Dr Paul Glasser, Chair Fellowship Committee

\section{Maria Salit-Gitelson Tell Memorial Fellowship}

Subjects: Lithuanian Jewish history.

Purpose: To support original doctoral or postdoctoral research in the field of Lithuanian Jewish history, the city of Vilnus in particular, at the YIVO Library and Archives.

Eligibility: Applicants must carry out original doctoral or postdoctoral research in the field of Lithuanian Jewish history and give a public lecture at the end of the tenure of the Fellowship.

Level of Study: Doctorate, Postdoctorate

Type: Fellowship

Value: US $\$ 1,500$

Length of Study: 1-3 months

Frequency: Annual

Study Establishment: YIVO Library and Archives

Country of Study: United States of America

Application Procedure: Applicants must send a cover letter, curriculum vitae, research proposal and 2 letters of support through regular mail, fax or email.

Closing Date: December 31st

For further information contact:

Email: pglasser@yivo.cjh.org

Contact: Dr Paul Glasser, Chairman - Fellowship Committee

\section{Natalie and Mendel Racolin Memorial Fellowship}

Subjects: East European Jewish history.

Purpose: To support original doctoral or postdoctoral research in the field of East European Jewish history at the YIVO Library and Archives.

Eligibility: Applicants must carry out original doctoral or postdoctoral research in the field of East European Jewish history and give a public lecture at the end of the tenure of the Fellowship.

Level of Study: Postdoctorate, Doctorate

Type: Fellowship

Value: US $\$ 1,500$

Length of Study: 1-3 months

Frequency: Annual

Study Establishment: YIVO Library and Archives

Country of Study: United States of America

Application Procedure: Applicants must send a cover letter, curriculum vitae, research proposal and 2 letters of support through regular mail, fax or email.

Closing Date: December 31st

For further information contact:

Email: pglasser@yivo.cjh.org

Contact: Dr Paul Glasser, Chairman - Fellowship Committee 
Professor Bernard Choseed Memorial Fellowship

Subjects: East European Jewish studies.

Purpose: To financially support doctoral and postdoctoral students who conduct research.

Eligibility: Applicants are required to give a public lecture.

Level of Study: Doctorate, Postdoctorate

Type: Fellowship

Value: US $\$ 7,500$

Length of Study: 1-3 months

Frequency: Annual

Country of Study: United States of America

Application Procedure: Applicants must submit a curriculum vitae, a

research proposal and 2 letters of support through regular mail, fax or email.

Closing Date: Decemeber 31st

For further information contact:

Email: pglasser@yivo.cjh.org

Contact: Dr Paul Glasser, Chair, Fellowship Committee

\section{Rose and Isidore Drench Memorial Fellowship}

Subjects: American Jewish history with a focus on Jewish labor movement.

Purpose: To encourage research in American Jewish history.

Eligibility: Applicants are required to give a public lecture.

Level of Study: Postdoctorate, Doctorate

Type: Fellowship

Value: US $\$ 2,500$

Length of Study: $1-3$ months

Frequency: Annual

Application Procedure: Applicants must submit their curriculum vitae, a research proposal and 2 letters of support through regular mail, fax or email.

Closing Date: December 31st

For further information contact:

Email: pglasser@yivo.cjh.org

Contact: Dr Paul Glasser, Chair Fellowship Committee

\section{Samuel and Flora Weiss Research Fellowship}

Subjects: Polish Jewry or Polish-Jewish relations during the Holocaust period.

Purpose: To support research on the destruction of Polish Jewry or on Polish-Jewish relations during the Holocaust period.

Eligibility: Applicants must carry out original research on the destruction of Polish Jewry or on Polish-Jewish relations during the Holocaust period and give a written summary of the research carried out. The research should result in a scholarly publication.

Level of Study: Doctorate

Type: Fellowship

Value: US $\$ 2,500$

Frequency: Annual

Application Procedure: Applicants must send a cover letter curriculum vitae, research proposal and 2 letters of support through regular mail, fax or email.

Closing Date: December 31st

Additional Information: A public lecture at the end of the tenure of the Fellowship is optional.

For further information contact:

Email: pglasse@yivo.cjh.org

Contact: Dr Paul Glasser, Chairman - Fellowship Committee

\section{Vivian Lefsky Hort Memorial Fellowship}

Subjects: Yiddish literature.

Purpose: To support original doctoral or postdoctoral research in the field of Yiddish literature.

Eligibility: Applicants must carry out original doctoral or postdoctoral research in Yiddish literature and give a public lecture at the end of the tenure of the Fellowship.

Level of Study: Doctorate, Postdoctorate

Type: Fellowship

Value: US\$2,000
Length of Study: 1-3 months

Frequency: Annual

Study Establishment: YIVO Library and Archives

Country of Study: United States of America

Application Procedure: Applicants must send a cover letter, curriculum vitae, research proposal and 2 letters of support through regular mail, fax or email.

Closing Date: December 31st

For further information contact:

Email: pglasser@yivo.cjh.org

Contact: Dr Paul Glasser

\section{Vladimir and Pearl Heifetz Memorial Fellowship in Eastern European Jewish Music}

Subjects: Eastern European Jewish Music.

Purpose: To assist undergraduate, graduate and postgraduate researchers defray expenses connected with research in YIVO's music collection at the YIVO Archives and Library.

Eligibility: Undergraduate, graduate and postgraduate researchers who will carry on research in YIVO's music collection at the YIVO Archives and Library.

Level of Study: Graduate, Postgraduate, Undergraduate

Type: Fellowship

Value: US $\$ 1,500$

Frequency: Annual

Study Establishment: YIVO's music collection

Country of Study: United States of America

Application Procedure: Applicants must send a cover letter, curriculum vitae, research proposal and 2 letters of support through regular mail, fax or email.

Closing Date: December 31st

Funding: Foundation

Additional Information: A written summary of one's research is required; a public lecture is optional.

For further information contact:

Email: pglasser@yivo.cjh.org

Contact: Dr Paul Glasser, Chaiman-Fellowship Committee

Workmen's Circle/Dr Emanuel Patt Visiting Professorship

Subjects: Eastern European Jewish Studies.

Purpose: To support postdoctoral research at the YIVO Library and Archives.

Level of Study: Postdoctorate

Type: Fellowship

Value: US $\$ 5,000$

Length of Study: 3 months

Frequency: Annual

Study Establishment: YIVO Library and Archives

Country of Study: United States of America

Application Procedure: Applicants must send a covering letter, curriculum vitae, research proposal and 2 letters of support through regular mail, fax or email.

Closing Date: December 31st

Additional Information: The visiting faculty member should give a public lecture at the end of the award's tenure.

For further information contact:

Email: pglasser@yivo.cjh.org

Contact: Dr Paul Glasse

\section{YORKVILLE UNIVERSITY}

Yorkville Landing Suite 102, 100 Woodside Lane, Fredericton, NB, E3C 2R9, Canada Tel: (1) 5064541220

Fax: (1) 5064541221

Email: info@yorkvilleu.ca

Website: www.yorkvilleu.ca 
Yorkville University, established in 2003 in Fredericton, New Brunswick, is private and non-denominational, specializing in practice-oriented graduate level academic programmes.

\section{Jacob Markovitz Memorial Scholarship}

Subjects: Counselling psychology.

Purpose: To support graduate students in the helping professions at a number of academic institutions.

Eligibility: Open to all students with Canadian citizenship or with landed immigrant status in Canada who are registered in a programme at the Yorkville University. Only first time applicants are eligible to apply.

Level of Study: Postgraduate
Type: Scholarship

Value: 50 per cent of first year tuition

Frequency: Annual

Study Establishment: Yorkville University

Country of Study: Canada

No. of awards offered: $2-4$

Closing Date: November 26th

Funding: Trusts

Contributor: Jacob Markovitz Memorial Scholarship Fund

Additional Information: If granted a scholarship one must maintain a 3.0 average in each trimester for the duration of the scholarship grant. 